\title{
Development and fabrication of disease resistance protein in recombinant Escherichia coli
}

\author{
Sefli Sri Wahyu Effendi ${ }^{1 \dagger}$, Shih-I Tan ${ }^{1 \dagger}$, Chien-Hsiang Chang ${ }^{1}$, Chun-Yen Chen², Jo-Shu Chang ${ }^{1,3,4}$ \\ and I-Son $\mathrm{Ng}^{1 *}$ (D)
}

\begin{abstract}
Cyanobacteria and Spirulina produce C-phycocyanin (CPC), a water soluble protein associated pigment, which is extensively used in food and pharmaceutical industries. Other therapeutic proteins might exist in microalgal cells, of which there is limited knowledge. Such proteins/peptides with antibiotic properties are crucial due to the emergence of multi-drug resistant pathogens. In addition, the native expression levels of such disease resistant proteins are low, hindering further investigation. Thus, screening and overexpression of such novel proteins is urgent and important. In this study, a protein which was identified as a putative disease resistance protein (DRP) in the mixture of Spirulina product has been explored for the first time. To improve protein expression, DRP was cloned in the pET system, co-transformed with pRARE plasmid for codon optimization and was significantly overexpressed in E. coli BL21(DE3) under induction with isopropyl- $\beta$-D-1-thiogalactopyranoside (IPTG). Furthermore, soluble DRP exhibited intense antimicrobial activity against predominant pathogens, and an inhibition zone of 1.59 to $1.74 \mathrm{~cm}$ was obtained for $E$. coli. At a concentration $4 \mathrm{mg} / \mathrm{mL}$, DRP significantly elevated the growth of L. rhamnosus ZY up to twofold showing probable prebiotic activities. Moreover, DRP showed potential as an effective antioxidant, and the scavenging ability for ROS was in the order of hydroxyl > DPPH > superoxide radicals. A putative disease resistance protein (DRP) has been identified, sequenced, cloned and over-expressed in E. coli as a functional protein. Thus expressed DRP showed potential anti-microbial and antioxidant properties, with promising therapeutic applications.
\end{abstract}

Keywords: Disease resistance protein, Recombinant technology, Rare codon, Antibacterial, Antioxidant

\section{Introduction}

Microalgae, including diatoms of Bacillariophyta, green algae Chlorella sp. and blue-green algae cyanobacteria, serve as a natural carbon sink, and are known as a sustainable feedstock for biodiesel and biofuel production. The protein rich microalgal biomass is also known for the co-production of a number of high-value products viz., carbohydrates, bioplastic polymers, cosmetics, and food

\footnotetext{
*Correspondence: yswu@mail.ncku.edu.tw

tSefli Sri Wahyu Effendi and Shih-I Tan contributed equally to this work ${ }^{1}$ Department of Chemical Engineering, National Cheng Kung University, Tainan 701, Taiwan

Full list of author information is available at the end of the article
}

additives (Li et al. 2018; Allen et al. 2018). Microalgae and cyanobacteria are naturally protein-rich (Teuling et al. 2019), and C-phycocyanin (CPC) is the dominant phycobiliprotein commonly seen in cyanobacteria (Eriksen 2008). CPC has been explored in pharmaceuticals as antibacterial, anticancer, antioxidants, health supplements, and vitamins mainly due to the increasing demand for alternative antimicrobial agents to counteract the rising antibiotic resistance in pathogens (Singh et al. 2011; Waghmare et al. 2016). The presence of carotenoids and chlorophylls alongside CPC is the major bottleneck in the CPC purification process. Thus the development of a pigment extraction cascade without any loss in essential proteins is vital (Marzorati et al. 2020). Other than that, 
extraction cascades have also been successfully applied to isolate fatty acids from the spent biomass after CPC extraction, which consisted of high amounts of PUFAs (Imbimbo et al. 2019). Furthermore, microalgae and cyanobacteria might possibly contain other therapeutic proteins/peptides with applications as novel drugs. However, discovery, extraction and purification of such novel algal proteins in a sustainable way is a critical issue.

Tandem mass spectrometry serves as a powerful tool to identify proteins and studying the relationship between protein functions and cellular behavior. Protein discovery related to a specific function is essential for advancement in emerging technologies such as synthetic biology which helps in solving global issues (Coon et al. 2005). For instance, the presence of asiaticoside in ethyl acetate extract from medicinal plant Centella asiatica Urban was confirmed by LC-MS (Gupta et al. 2018). Therefore, the advent of high-throughput tandem mass spectrometry invigorated proteomics - the classification of the protein complement expressed by the genome of an organism (Wolters et al. 2001). The most common application of proteomics is in the medical sector for therapeutics and diagnosis by identifying novel biomarkers of disease. Recently, Marchand and his colleagues developed a non-natural amino acid system in E. coli which was integrated by proteomics (Marchand et al. 2019). Moreover, proteomics plays a vital role in revealing the metabolism under different physiological stimulation and discovering new proteins for unique applications. For example, a robust multiple copper oxidase from an electrogen Proteus Hauseri ZMD44 was discovered and overexpressed in E. coli to be applied in gold recovery, because the organism exhibited tolerance to copper ions by automatically overexpressing the multiple copper oxidase $(\mathrm{Ng}$ et al. 2016; Tan et al. 2017).

Recombinant technology has become an essential tool at hand for high-level production of heterologous proteins (Rosano et al. 2014). The choice of the host cell and it's protein synthesizing machinery is decisive in initiating the outline of the whole process. As a model organism, E. coli has been routinely used to produce heterologous proteins (Schlegel et al. 2017). Also, the advantages of using $E$. coli over other organisms are wellknown, such as doubling time in glucose-salts media is about $20 \mathrm{~min}$, and it is able to reach high cell density easily and stationary phase can be attained in a few hours (Sezonov et al. 2007). Previous studies have reported that CPC from cyanobacteria was successfully expressed in $E$. coli (Zhao et al. 2006; Guan et al. 2007; Yu et al. 2016).

In this study, a putative disease resistance protein (DRP) was screened from the mixture of Spirulina product and identified by MS/MS for the first time. Afterward, the whole DNA sequence of DRP was synthesized, cloned into pET21a(+) and further expressed in E. coli. The optimization of DRP production involved optimal codon usage and temperature effect. Furthermore, the novel functionalities of DRP are explored regarding antimicrobial activity, prebiotic promoting activity and antioxidant activity.

\section{Materials and methods}

\section{Protein identification from nature product}

The natural product, which was initially extracted from Spirulina species, was purchased from Febico Bio-Tec, Taiwan. The powder was dissolved in deionized water to a concentration of $10 \mathrm{~g} / \mathrm{L}$, and then the solution was centrifuged to collect the supernatant. The protein concentration of the supernatant was measured by Bradford assay (Bio-Rad, USA) with bovine serum albumin (BSA) as a protein standard. The concentration of the protein solution was then adjusted to $1 \mathrm{~g} / \mathrm{L}$. The final solution was subjected to sodium dodecyl sulfate-polyacrylamide gel electrophoresis (SDS-PAGE) to analyze the protein pattern, which was visualized by staining with Coomassie blue R-250. The targeted protein bands were sent for tandem MS/MS analysis.

\section{Synthesis and cloning of DRP and co-transformation with PRARE plasmid}

After identifying the amino acid sequence by MS/MS analysis, the DNA sequence of DRP was deduced by reverse translation using Vector NTI (Life Technologies, USA) as shown in Additional file 1: Figure S1, and then the entire gene sequence was synthesized by IDT (Coralville, USA). The DRP fragment was amplified by polymerase chain reaction and cloned into pET21a $(+)$ plasmid at the restriction sites NdeI and XhoI (NEB, USA) (Additional file 1: Figure S2). The strains, plasmids, and primers used in this study are listed in Table 1.

\section{Culture conditions and overexpression of recombinant DRP}

The Disease resistance protein (DRP) was cloned and expressed in E. coli BL21(DE3). First, recombinant colonies were grown on LB plates (1.5\% tryptone, $1.5 \% \mathrm{NaCl}$ and $0.5 \%$ yeast extract) with antibiotics $(50 \mathrm{mg} / \mathrm{L}$ ampicillin for pET21a(+)-DRP and $12.5 \mathrm{mg} / \mathrm{L}$ chloramphenicol for pRARE) at $37^{\circ} \mathrm{C}$ for $12 \mathrm{~h}$. Next, a single colony was inoculated in LB medium with appropriate antibiotics for pre-culture at $37^{\circ} \mathrm{C}$ for $12 \mathrm{~h}$ with shaking at $200 \mathrm{rpm}$. Then, the cells were diluted 1:100 in LB medium with antibiotics and cultured for about $3 \mathrm{~h}$. Growth was monitored by measuring the biomass or optical density at $600 \mathrm{~nm}\left(\mathrm{OD}_{600}\right)$ using the spectrophotometer (SpectraMax 340, Molecular Devices, USA). As the $\mathrm{OD}_{600}$ reached $0.6 \sim 0.8$, the cells were induced by the addition 
Table 1 Strains, plasmids and primers used in this study

\begin{tabular}{|c|c|c|}
\hline Name & Description & Remark \\
\hline \multicolumn{3}{|l|}{ E. coli strains } \\
\hline $\mathrm{DH} 5 \mathrm{a}$ & $\begin{array}{l}\text { F-, } \Delta(\arg F-l a c) 169, \varphi 80 \text { dlacZ58(M15), } \triangle \text { phoA8, glnX44(AS), } \lambda-\text {, deoR481, rfbC1, gyrA96(NalR), recA1, } \\
\text { endA1, thiE1, hsdR17 }\end{array}$ & Molecular cloning \\
\hline BL21(DE3) & $\mathrm{F}^{-}$ompT gal dcm lon hsdS ${ }_{B}\left(r_{B}^{-} m_{B}^{-}\right) \lambda\left(\right.$ DE3 [lacl lacUV5-T7p07 ind1 sam7 nin5]) $\left[\mathrm{malB}^{+}\right]_{\mathrm{K}-12}\left(\lambda^{\mathrm{S}}\right)$ & T7-based expression \\
\hline \multicolumn{3}{|c|}{ 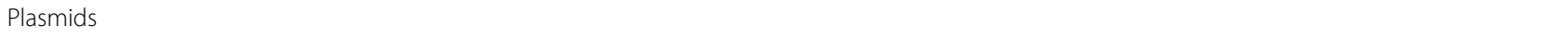 } \\
\hline pET21a & 3802 bp, Km, RSF ori, T7 promoter, T7 terminator, Lacl & This study \\
\hline pET21a-DRP & 2922 bp, Cm², pUC ori, Placl promoter, B0034 RBS, sfGFP & This study \\
\hline pRARE & 2935 bp, CmR, pUC ori, Pl promoter, B0034 RBS, sfGFP & Tegel et al. 2010 \\
\hline \multicolumn{3}{|l|}{ Primers } \\
\hline Ndel-DRP-F & GCCATATGTTGAAGGACGAATTGC & This study \\
\hline Xhol-DRP-R & TGCTCGAGTCATTAATGGTGGTGATGGTGGTGGCTACCTCTTGG & This study \\
\hline
\end{tabular}

Restriction sites have been underlined

of $0.1 \mathrm{mM}$ IPTG and further incubated at 25 and $30{ }^{\circ} \mathrm{C}$ for up to $12 \mathrm{~h}$. Finally, the cells were harvested by centrifuging at $12,000 \times g$ for $10 \mathrm{~min}$ and washed with deionized water for two times. Then, the OD was adjusted to an appropriate concentration, and the cells were disrupted using a One-Shot high-pressure crusher to obtain soluble DRP. The whole-cell proteins and the soluble DRP protein were analyzed by SDS-PAGE.

\section{Antibacterial activity}

Antibacterial activity determination was performed by the agar well diffusion method, which was seeded with pathogen strains (Rani et al. 2018). Aeromonas hydrophila, Bacillus cereus, Escherichia coli, and Staphylococcus aureus were inoculated in $20 \mathrm{~mL}$ of LB agar at $2 \%(v / v)$. For testing the antibacterial activity, various concentrations of soluble protein DRP were absorbed on the filter paper (diameter $\pm 0.25 \mathrm{~cm}$ ) in a cooled agar plate. The size of the bacterial inhibition zone for each concentration was measured after culturing at $37^{\circ} \mathrm{C}$ for $6 \mathrm{~h}$. The positive control was CPC from natural product purchased from Febico Bio-Tec, Taiwan. All experiments were performed in duplicate independently.

\section{Prebiotic activity}

The prebiotic activity test was carried out by culturing $5 \%$ $(v / v)$ of Lactobacillus rhamnosus ZY on $20 \mathrm{~mL}$ of MRS medium in a $100 \mathrm{~mL}$ of Erlenmeyer flask (Lai et al. 2019). Each culture flask was supplemented with different amounts of BL21(DE3) wild type and the recombinant strain expressing DRP. The cells were cultured at $37{ }^{\circ} \mathrm{C}$ with shaking at $200 \mathrm{rpm}$ for $12 \mathrm{~h}$. After that, samples were taken and diluted with deionized water $10^{7}$ times before the screening process on MRS agar plate. The colony-forming units (CFU) of prebiotics were counted after incubation at $37^{\circ} \mathrm{C}$ for $24 \mathrm{~h}$.

\section{Antioxidant activity}

DRP samples were prepared in different protein concentrations (i.e., $0.1 \sim 4 \mathrm{mg} / \mathrm{mL}$ ). Phycocyanin (CPC), one of the functional proteins, was extracted from the commercial product (Febico Bio-Tec, Taiwan) and diluted to $1 \mathrm{mg} / \mathrm{mL}$ as a control solution.

\section{$D P P H$ radical scavenging assay}

The $\alpha, \alpha$-diphenyl- $\beta$-picrylhydrazil (DPPH) radical scavenging activity was performed according to a previous study (Xia et al. 2011) with some modification. First, $0.039 \mathrm{~g}$ of DPPH was added to $1 \mathrm{~mL}$ of anhydrous alcohol, and the DPPH solution was diluted 100 times with anhydrous alcohol. A $100 \mu \mathrm{L}$ of DPPH solution was mixed with $100 \mu \mathrm{L}$ of protein sample in a centrifuge tube. Samples were incubated in darkness at $25^{\circ} \mathrm{C}$ for $30 \mathrm{~min}$. After the reaction was completed, the precipitate was removed by centrifugation at $12,000 \times g$ for $1 \mathrm{~min}$. A control was measured by replacing the protein sample with water. The mixture reaction $\left(\mathrm{A}_{\mathrm{i}}\right)$ and control $\left(\mathrm{A}_{0}\right)$ samples were transferred into 96-well microplate and the absorbance was measured at the wavelength of $517 \mathrm{~nm}$. The DPPH scavenging rate was determined using the following equation:

DPPH Scave nging rate $(\%)=\left[1-\left(A_{i}-A_{0}\right) / A_{i}\right] \times 100 \%$.

\section{$\mathrm{OH}^{-}$radical scavenging assay}

The hydroxyl scavenging assay was conducted according to the Fenton reaction (Sies et al. 1993; Wang et al. 2017; Huang et al. 2019) with some modification. First, $0.085 \mathrm{~g}$ of $\mathrm{FeSO}_{4} \cdot 7 \mathrm{H}_{2} \mathrm{O}$ was added to $50 \mathrm{~mL}$ of $\mathrm{H}_{2} \mathrm{O}_{2}$ to prepare a $\mathrm{FeSO}_{4(\mathrm{aq})}$ solution $(6 \mathrm{mM})$. Then, $200 \mu \mathrm{L}$ of $\mathrm{FeSO}_{4(\mathrm{aq})}$, $100 \mu \mathrm{L}$ of sodium salicylate solution $(10 \mathrm{mM})$, and $20 \mu \mathrm{L}$ protein sample were added in a centrifuge tube, mixed 
well and incubated for $30 \mathrm{~min}$. The hydroxyl radical reacts with salicylic acid to form 2,3-dihydroxybenzoic acid which absorbs UV light at $510 \mathrm{~nm}$. After the reaction was completed, the precipitate was removed by centrifugation at $2000 \times g$ for $5 \mathrm{~min}$. The reaction mixture was transferred into a 96-well microplate and the absorbance $A_{i}$ was measured. The background absorbance $A_{j}$ was measured by replacing the protein sample with water, and the blank absorbance $\mathrm{A}_{0}$ was measured by replacing the sodium salicylate solution with water. The following formula was used for the calculation of the scavenging rate of hydroxyl radical $\left(\mathrm{OH}^{-}\right)$:

$\mathrm{OH}^{-}$Scavenging rate $(\%)=\left[1-\left(\mathrm{A}_{\mathrm{i}}-\mathrm{A}_{0}\right) / \mathrm{A}_{j}\right] \times 100 \%$.

\section{$\mathrm{O}_{2}^{-}$radical scavenging assay}

The superoxide radical scavenging activity was performed as reported previously (Patel et al. 2018) with some modifications. First, a $10 \mathrm{mM}$ pyrogallol $\left(\mathrm{C}_{6} \mathrm{H}_{6} \mathrm{O}_{3}\right)$ solution in $10 \mathrm{mM} \mathrm{HCl}$ and a $50 \mathrm{mM}$ Tris- $\mathrm{HCl}$ buffer at pH 8.2 were prepared. Then, $500 \mu \mathrm{L}$ of Tris $-\mathrm{HCl}$ buffer, $470 \mu \mathrm{L}$ distilled water, and $10 \mu \mathrm{L}$ of protein sample were added in a centrifuge tube, mixed well and incubated for $20 \mathrm{~min}$ at $25{ }^{\circ} \mathrm{C}$. A $200 \mu \mathrm{L}$ of the mixture was added to $20 \mu \mathrm{L}$ of preheated $10 \mathrm{mM}$ pyrogallol solution at $25^{\circ} \mathrm{C}$. The reaction mixture was transferred to a 96-well microplate and the kinetic absorbance $\left(\mathrm{A}_{\mathrm{i}}\right)$ was measured at the wavelength of $325 \mathrm{~nm}$ for $2 \mathrm{~min}$. The oxidation rate of pyrogallol $\Delta \mathrm{A}$ was estimated by calculating the difference of absorbance per minute in the linear range. The auto-oxidation rate of pyrogallol $\Delta \mathrm{A}_{0}$ was also estimated as above by replacing protein samples with pyrogallol solution. The following formula calculated the scavenging rate of superoxide anion $\left(\mathrm{O}_{2}{ }^{-}\right)$:

$$
\mathrm{O}_{2}^{-} \text {Scavenging rate }(\%)=\left(1-\Delta A / \Delta A_{0}\right) \times 100 \% \text {. }
$$

\section{Results and discussion Identification of disease resistance protein from nature product}

The native proteins from the commercial product were analyzed by SDS-PAGE (Fig. 1). The results showed a dominant band at a molecular weight of $17 \mathrm{kDa}$ (NP-17), which was indicated to be the CPC beta subunit with $30 \%$ coverage by tandem MS analysis (Table 2). It is reasonable that the dominant band was CPC, because Spirulina species are known as a rich source of bioactive products, one of which was CPC (Demay et al. 2019). Besides, CPC has several functional properties such as anti-oxidative function, anti-inflammatory activity, anti-cancer function, immune enhancement function, liver, and kidney

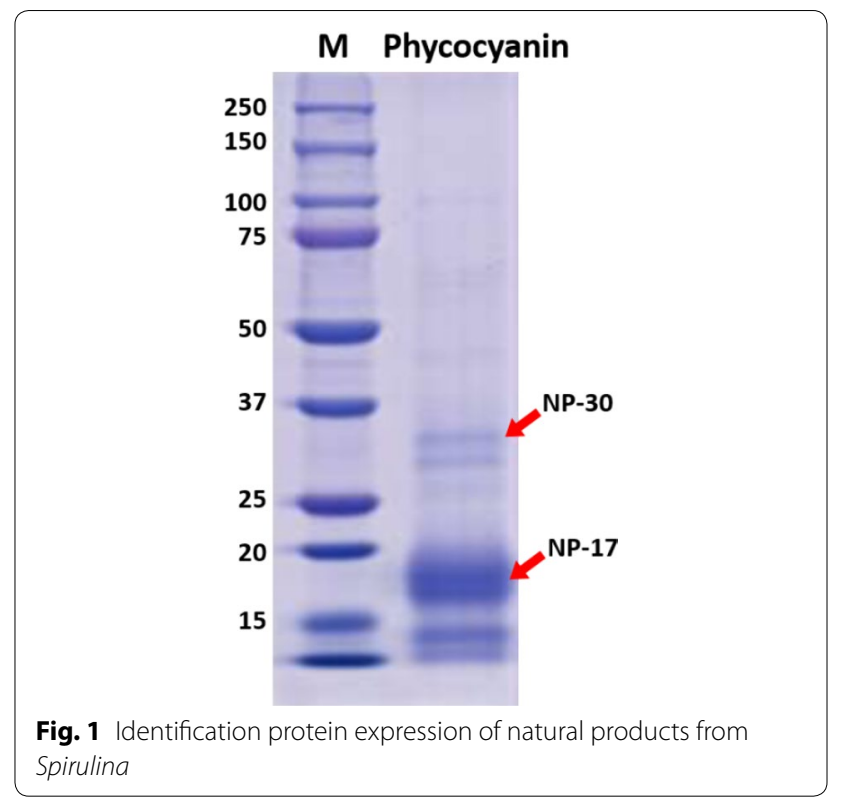

protection and other pharmacological effects (Jiang et al. 2017).

Another protein at a molecular weight of $30 \mathrm{kDa}(\mathrm{NP}$ 30) was observed, which was further identified as a putative disease resistance protein (DRP) (Table 2). Interestingly, the homologous protein of DRP was present in a higher plant, Dichanthelium oligosanthes, according to the OEL30137 sequence in the GenBank database. We considered that DRP might be present in the natural product purchased from Febico Bio-Tec. On the other hand, the coverage of DRP from MS/MS result was only $5 \%$, because it was present in trace amounts in the natural product, and has never been reported previously. Consequently, the whole DNA sequence for DRP was synthesized artificially and cloned into the pET21a $(+)$ plasmid for overexpression in E. coli. The functional properties of the over-expressed DRP were further explored.

\section{Over-expression of recombinant DRP in E. coli}

The DRP gene acquired by DNA synthesis was amplified by PCR (Fig. 2a), and cloned in pET21a(+) vector. The recombinant gene expression was driven by $\mathrm{T} 7 / \mathrm{lac}$ promoter and overexpressed in E. coli BL21 (DE3). Protein expression induced by IPTG was evaluated by SDS PAGE analysis. The recombinant protein was not overexpressed under the experimental conditions with the single plasmid (Fig. 2b).

Next, to enhance the expression level of DRP in E. coli, pRARE plasmid was co-transformed with pET21a-DRP as dual plasmids and was cultured at $37^{\circ} \mathrm{C}$ for $12 \mathrm{~h}$. The pRARE plasmid was used to improve protein expression as it contains the rare codon encoding tRNAs and 
Table 2 MASCOT analysis of protein identification and full sequence of target protein

\begin{tabular}{|c|c|c|c|c|c|c|}
\hline No & Protein name & Accession no. & Score & Mw (kDa) & PI & Coverage (\%) \\
\hline NP-17 & $\begin{array}{l}\text { C-phycocyanin beta subu- } \\
\text { nit, Chain B }\end{array}$ & 1GHO_B & 115 & 18.0 & 4.96 & 30 \\
\hline NP-30 & $\begin{array}{l}\text { Putative disease resistance } \\
\text { protein (DRP), partial }\end{array}$ & OEL30137 & 141 & 27.8 & 6.20 & 5 \\
\hline \multicolumn{7}{|c|}{ Protein sequence of DRP } \\
\hline \multicolumn{7}{|c|}{$\begin{array}{l}\text { MLKDELQRLQGCLKDADTKRRSGNESAAIWVSQIRDAAYEAENVLEVVDHMEKRNRLKKGFMGAVSRYARLPSDLITLHKVGIEIERIRRKVSEISESANRLKILDLGNDELEN- } \\
\text { SHLGDESPQDYRLVHQNFEDVTVVVGFEDEQKEIVEELVEKDGKLSVVSIVGMGGAGKTTLARKVYTSDKIKQRFETIAWVTVSQKFKGADLLKDIMKQIMGSEYKPR- } \\
\text { QIDQLEEYELGGKIQNFLVQKKNRSLVPRGS }\end{array}$} \\
\hline
\end{tabular}

The underlined amino acid sequence is identified by MS/MS and to be the $5 \%$ coverage of DRP
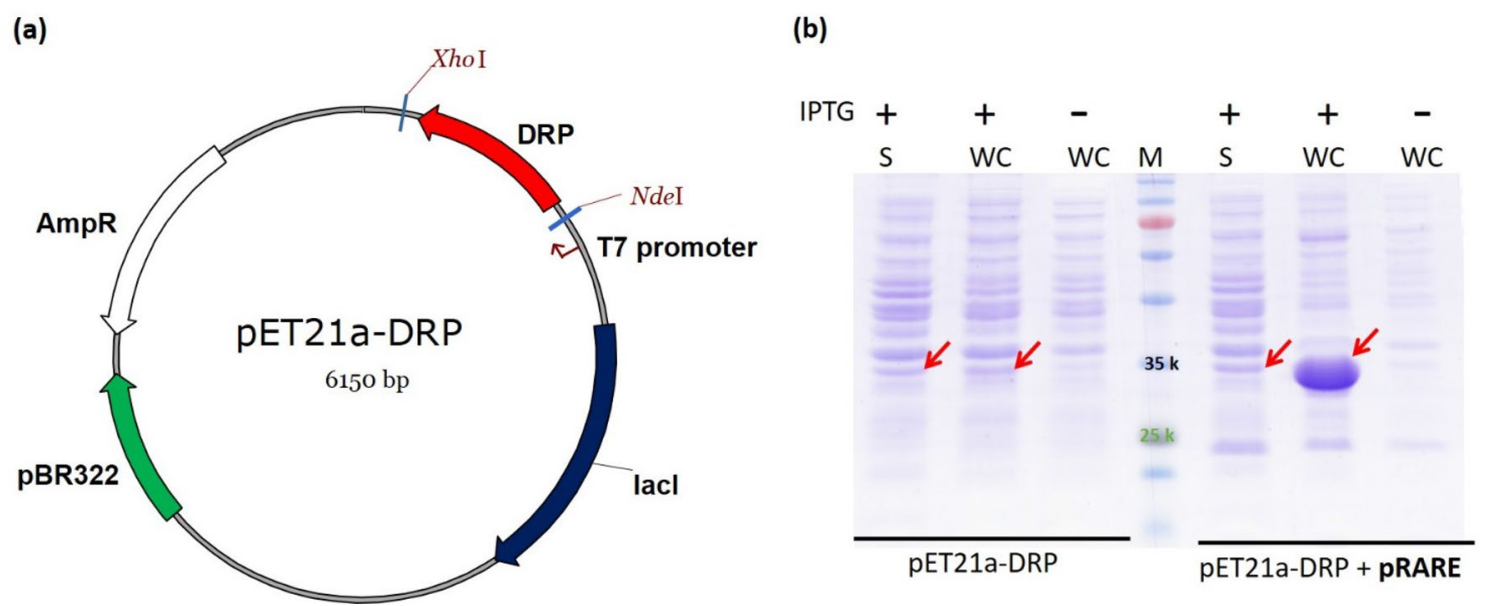

Fig. 2 a Gel electrophoresis analysis of DRP sequence by colony PCR. The N1 and N2 was the negative control by E. coli and pET21a(+) plasmid in the PCR reaction. The P indicates the positive control with DNA synthesis of DRP as a template, while numbers 1-4 represent each colony from pET21a-DRP in E. coli. M is the molecular weight of DNA marker. The targeted size is 832 bp. $\mathbf{b}$ DRP and DRP co-expression with pRARE vector for rare-codon optimization by SDS-PAGE analysis. S and WC represent the proteins from soluble and whole cell. The red arrows indicate the size of DRP

optimize codon usage for heterologous protein expression (Liu et al. 2006). As expected, the recombinant protein was successfully expressed at approximately $30 \mathrm{kDa}$; however, most DRP was aggregated into the inclusion body (Fig. 2b). To express the DRP as a soluble protein, the post- IPTG induction temperature was reduced to $30{ }^{\circ} \mathrm{C}$ and $25^{\circ} \mathrm{C}$ instead of $37^{\circ} \mathrm{C}$. This is because inclusion bodies are formed due to improper folding or conformation of the overexpressed protein at high temperature, and induction at low temperature might assist proper folding of the proteins. This was a common phenomenon when using E. coli to produce most of the heterologous protein (Yu et al. 2016). As a result (Fig. 3), it was obvious that the protein expression at lower temperatures was maintained at the same level as that of $37{ }^{\circ} \mathrm{C}$. Also, the soluble protein was significantly enhanced, and the highest soluble DRP was obtained by culturing at $25^{\circ} \mathrm{C}$. Due to the limited knowledge of DRP from commerical Spirulina extract, it is hard to evaluate the effect of posttranslational modification of DRP at this juncture. In this

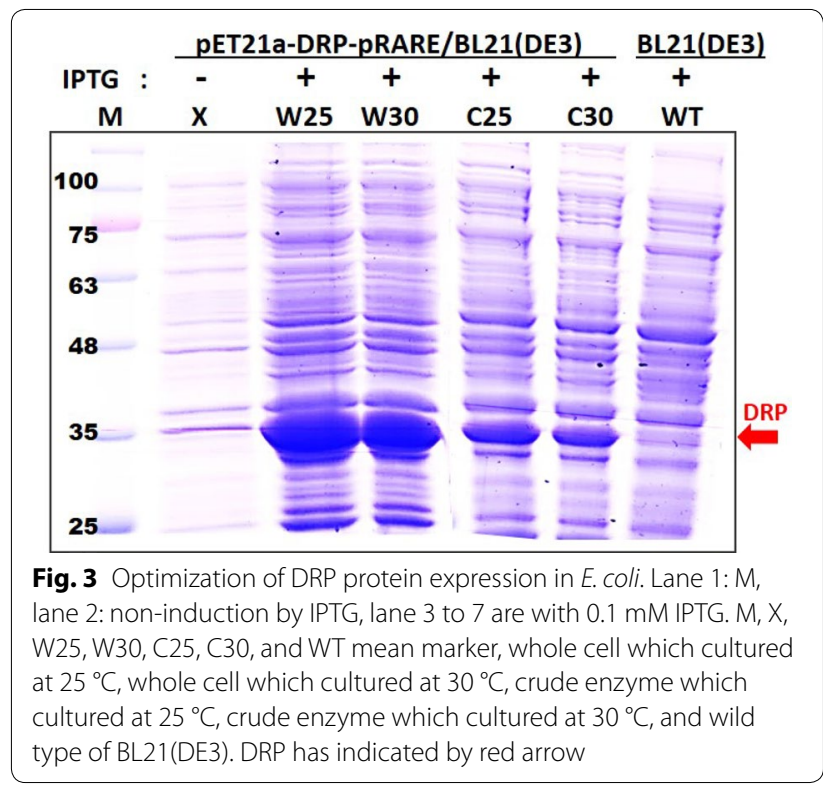


study, the DRP expressed in E. coli is without any posttranslational modification. Thus, we need to investigate the functional properties of DRP.

\section{Antibacterial activity of DRP}

The recombinant DRP present in the cell-free extract was screened for antimicrobial activity against some relevant pathogens, namely $S$. aureus and $B$. cereus which are Gram positive; E. coli and A. hydrophila which are Gramnegative (Additional file 1: Table S1, Fig. 4). Among the pathogen strains, $B$. cereus was the most sensitive towards the DRP at $30^{\circ} \mathrm{C}$ and $25^{\circ} \mathrm{C}$, with $0.99 \sim 1.91 \mathrm{~cm}$ and $1.01 \sim 1.86 \mathrm{~cm}$ clearance zone, respectively. Interestingly, S. aureus is also Gram-positive, but it was more resistant and showed the minimum clearance zone $(0.83 \sim 1.11 \mathrm{~cm})$. The resistance towards CPC was similar for S. aureus. In contrast, other studies have reported that $S$. aureus has high sensitivity compared to Gramnegative bacteria towards CPC from exopolysaccharide of S. thermophilus GST-6 (Zhang et al. 2016). We considered that the antibacterial compound contained in soluble DRP was slightly different from the one reported by Zhang et al., thus affecting the capability of inhibition in different pathogen strains. Furthermore, $0.25 \mathrm{mg} /$ $\mathrm{mL}$ of DRP at $25^{\circ} \mathrm{C}$ and $30{ }^{\circ} \mathrm{C}$ have shown $1.59 \mathrm{~cm}$ and $1.74 \mathrm{~cm}$ of clearance zone for $E$. coli, which is a highly virulent pathogen in nature (Silhavy et al. 2010; Najdenski et al. 2013). Besides, extracted commercial CPC has

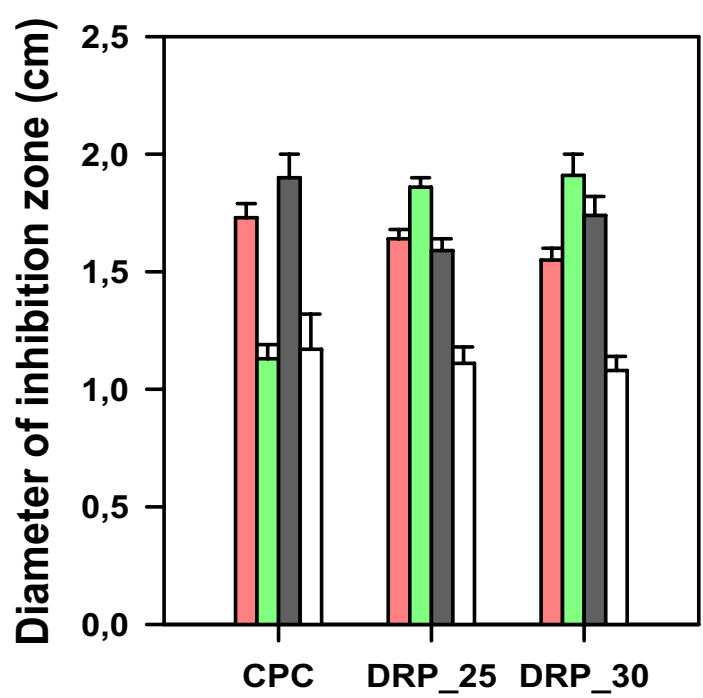

Fig. 4 Effect of protein added on the antibacterial activities of Aeromonas hydrophila (red bar), Bacillus cereus (green bar), Escherichia coli (grey bar), and Staphylococcus aureus (white bar). C-PC is the positive control, while DRP_25 and DRP_30 represent to samples incubator at $25^{\circ} \mathrm{C}$ and $30^{\circ} \mathrm{C}$, respectively. All the proteins concentrations are the same as $0.25 \mathrm{mg}$ the strongest inhibition ability for $E$. coli $(1.74 \mathrm{~cm})$. Also, the exopolysaccharides from the cyanobacteria Nostoc commune (Quan et al. 2015) was highly active against $E$. coli. A high proportion of such antibacterial compound producing strains might be associated with an ecological role, probably displaying defensive measures to maintain their niche, or allow the invasion of strains into established microbial communities (Gillor et al. 2008). On the other hand, both Spirulina CPC and the recombinant DRP showed substantial inhibition zones with an increase in protein concentration. The antibacterial activity of DRP at $25{ }^{\circ} \mathrm{C}$ and $30{ }^{\circ} \mathrm{C}$ is in the order of $B$. cereus $>$ E. coli $>$ A. hydrophila $>$ S. aureus.

\section{Prebiotic activity of DRP}

Figure 5 demonstrates the effect of adding different protein supplements on the growth of probiotic strain $L$. rhamnosus ZY. The evaluation was based on the CFU of $L$. rhamnosus ZY screened on MRS agar plate. After $24 \mathrm{~h}$, the CFU of L. rhamnosus $\mathrm{ZY}$ without protein addition was $6.2 \times 10^{8}$. It is interesting to note that low levels of DRP supplementation successfully promoted the prebiotic activity, even higher than that of $\mathrm{CPC}$ at the same concentration ( 0.5 to $2 \mathrm{mg}$ ). Meanwhile, the highest CFU was attained by adding $4 \mathrm{mg} / \mathrm{mL}$ of CPC and soluble DRP, and the cell count was elevated up to twofolds $\left(17.5 \times 10^{8}\right)$ and 1.5 -folds $\left(16.0 \times 10^{8}\right)$, respectively. Similar to antibacterial activity, the prebiotic activity was concentration-dependent. Despite this, the addition of WT-BL21(DE3) cell free extract seems to be inhibitory,

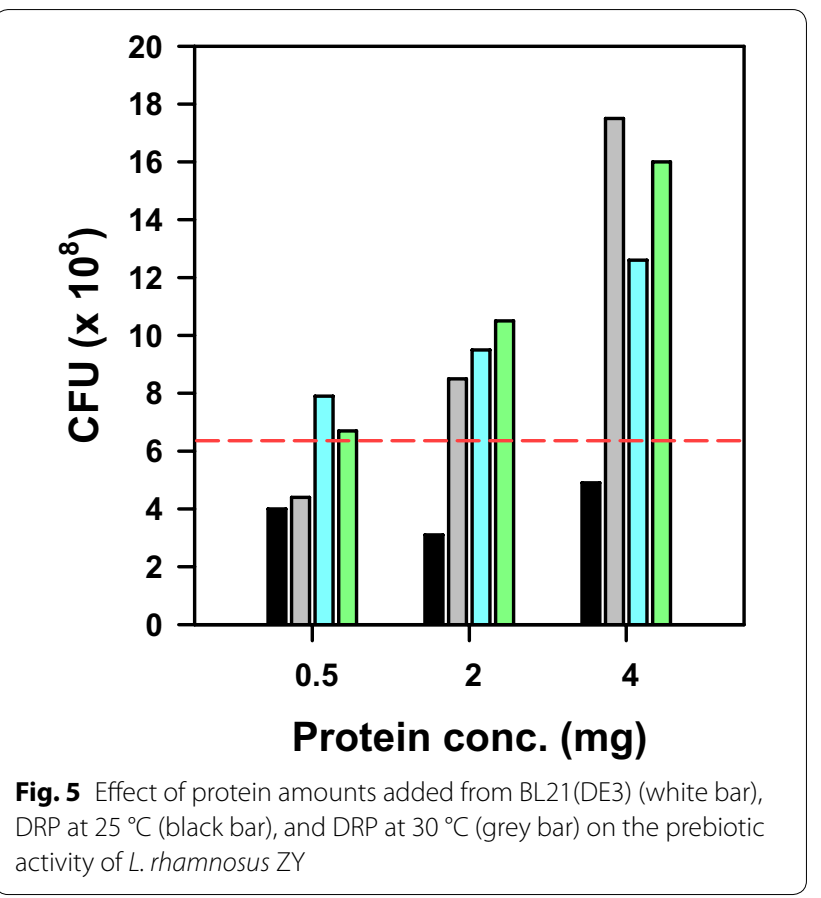


since the CFU declined as soluble extract of WTBL21(DE3) increased. Furthermore, the prebiotic activity of DRP was higher that the proteins obtained from Chlorella vulgaris FSP-E and Chlorella sorokiniana, since both the algal proteins attained only 7.8 to $8.7 \times 10^{8} \mathrm{CFU}$ using a high concentration of protein (Lai et al. 2019).

\section{Antioxidant activity of DRP}

The anti-oxidant potential of DRP was assessed by evaluating the scavenging potential of DRP for DPPH, hydroxyl, and superoxide radicals with a wide range of protein concentrations. DPPH is a stable nitrogen-centered free radical substance, and it is commonly used in free-radical scavenging assay (SánchezMoreno et al. 2002; Mahmoudi et al. 2020). Stable DPPH exhibits a violet color; and when the DPPH radical accepts an electron from an antioxidant compound, the color of DPPH turns yellow. The degree of discoloration indicates the scavenging potential of the antioxidant extract. Besides, it is most likely a decrease in absorbance caused by phenolic compounds in the reduction reaction between DPPH radicals and antioxidant molecules in protein. The results in Fig. 6a showed that the antioxidant activity of DRP expressed at $30^{\circ} \mathrm{C}$ is higher than
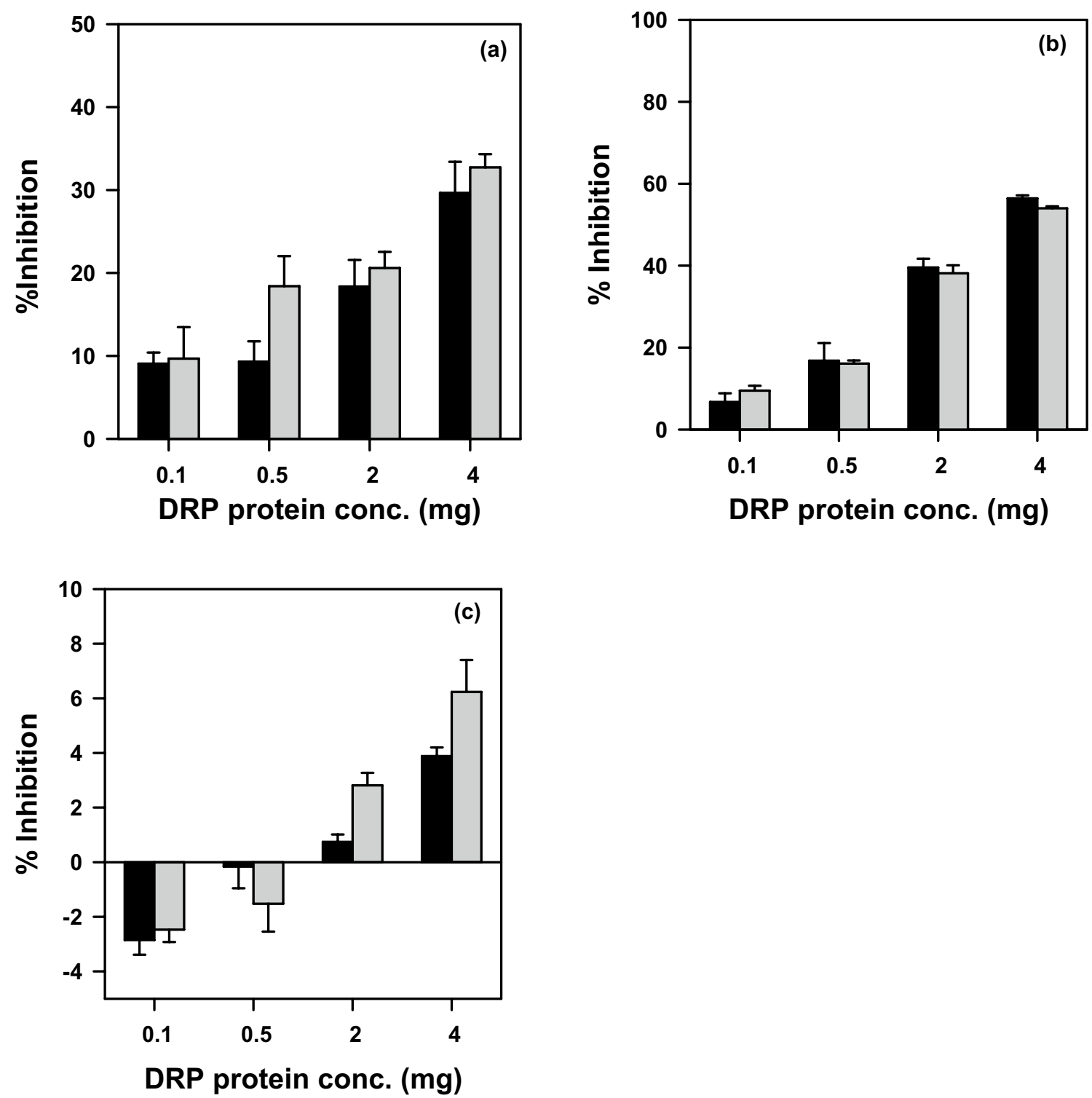

Fig. 6 Functional test based on (a) DPPH, (b) Hydroxyl, and (c) Superoxide radical scavenging activity of DRP protein, which cultured at $25^{\circ} \mathrm{C}($ black bar) and at $30^{\circ} \mathrm{C}$ (grey bar) 
that at $25^{\circ} \mathrm{C}$. The antioxidant activity in both the samples improved by increasing the concentration of DRP, and $4 \mathrm{mg} / \mathrm{mL}$ showed the highest rate at $32.7 \%$ and $29.6 \%$, respectively. The increasing of scavenging activity in protein extract might be due to the presence of antioxidant compounds, which are good electron donors (Easwar and Viswanatha 2020).

Hydroxyl radical is an extremely reactive free radical formed in a biological system. It has been implicated as a highly damaging species in free radical pathology, capable of damaging almost every molecule found in living cells. This radical has the capacity to join nucleotides in DNA and cause strand breakage (Kaur et al. 2019). In this study, the results showed that soluble DRP effectively scavenged the reactive hydroxyl radical, and the antioxidant activity reached $56.4 \%$ and $54.0 \%$ at $25{ }^{\circ} \mathrm{C}$ and $30{ }^{\circ} \mathrm{C}$, respectively (Fig. 6b). The hydroxyl radical scavenging activity of soluble DRP was higher than a previous study, which used Spirulina extract (Zayadi et al. 2020).

The superoxide radical scavenging activity results are shown in Fig. 6c. Among various concentrations of soluble DRP, only high concentrations ( 2 and $4 \mathrm{mg} / \mathrm{mL}$ ) scavenged superoxide radical about $0.7 \sim 6.2 \%$, while soluble DRP at 0.1 and $0.5 \mathrm{mg} / \mathrm{mL}$ had no superoxide radical scavenging activity. According to a previous study, the antioxidant activity against superoxide radical might be supported by CPC (Santiago-Morales et al. 2018).

By comparing the antioxidant activities of DRP and CPC from the commercial product as a control (Table 3), the extracted CPC revealed higher anti-oxidant potential than crude DRP at all assessments. Herein, DRP and CPC displayed the highest activity against hydroxyl radicals, which was $90.3 \%$ and $56.4 \%$, respectively. The difference between the effect of CPC and DRP on the DPPH scavenging activity was not significant; meanwhile, the superoxide scavenging activity of CPC was tenfolds higher compared to DRP. However, the protein concentration of DRP was apparently 4 times higher than that of CPC. The results suggested that the scavenging capability was truly influenced by pure phycocyanin, although at less amount. Besides, the antioxidant potential of crude protein from E. coli BL21(DE3) was also assessed; however, no antioxidant activity was detected (data not shown).

Furthermore, early studies from varied species exhibited high antioxidant activity. Zhang and his colleagues evaluated antioxidant activity from Lactobacillus plantarum C88 (2013) and microalgae strains (2019), including Chlorococcum sp., Scenedemus sp., and C. pyrenoidosa FACHB-9. The results demonstrated that originally microalgae strains displayed higher scavenging ability than L. plantarum C88 even though the concentration was four times lower, and it successfully scavenged DPPH and $\mathrm{OH}^{-}$radical about 36.5 58\% and $63.1 \sim 77.5 \%$, respectively. It is worth noting that most of the studies cited use a purified product. However, to our best knowledge, purification of the recombinant DRP is laborious and expensive. Recently, researchers have applied some techniques to modify the biological activities of polysaccharides and CPC as well as enhance the antioxidant ability. Box-Behnken design was utilized beneficially to improve the antioxidant potential of microalgae $P$. versicolor NCC466, which showed an anti-oxidant activity of $88.7 \%$ for $\mathrm{OH}^{-}$and $87.4 \%$ for $\mathrm{O}_{2}^{-}$(Gammoudi et al. 2019). Yu et al. (2016) successfully scavenged the three free radicals $\left(\mathrm{OH}^{-}, \mathrm{DPPH}\right.$, and $\left.\mathrm{O}_{2}^{-}\right)$by Synechocystis PCC6803 by combining Plackett-Burman design and Box-Behnken design which was up to 78,83 , and $64 \%$, respectively.

For a cost-effective process and screening a novel antioxidant agent candidate, this study successfully characterized the antioxidant activity of DRP using cell-free extract protein, which efficiently reduced process costs

Table 3 Comparison antioxidant activity of different protein sources

\begin{tabular}{|c|c|c|c|c|c|}
\hline \multirow[t]{2}{*}{ Protein sources } & \multicolumn{3}{|c|}{ Antioxidant scavenging activity (\%) } & \multirow[t]{2}{*}{ Concentration $(\mathrm{mg} / \mathrm{mL})$} & \multirow[t]{2}{*}{ Reference } \\
\hline & DPPH & $\mathrm{OH}^{-}$ & $\mathrm{O}_{2}^{-}$ & & \\
\hline Lactobacillus plantarum C88 & 52.2 & 85.2 & ND & 4 & Zhang et al. 2013 \\
\hline Chlorococcum sp. & 58.0 & 77.5 & ND & 1 & Zhang et al. 2019 \\
\hline Scenedemus sp. & 51.4 & 72.4 & ND & 1 & \\
\hline Chlorella pyrenoidosa FACHB-9 & 36.5 & 63.1 & ND & 1 & \\
\hline Phormidium versicolor NCC466 & ND & 88.7 & 87.4 & 1 & Gammoudi et al. 2019 \\
\hline Synechocystis PCC6803 & 83.0 & 78.0 & 64.0 & - & Yu et al. 2016 \\
\hline CPC (commercial) & 27.4 & 90.3 & 30.5 & 1 & This study \\
\hline DRP_25 ${ }^{\circ} \mathrm{C}$ & 29.6 & 56.4 & 3.9 & 4 & \\
\hline DRP_30 ${ }^{\circ} \mathrm{C}$ & 32.7 & 54.0 & 6.2 & 4 & \\
\hline
\end{tabular}

ND means not-determined 
due to non-intricated techniques. The crude extract with DRP showed the highest anti-oxidant activity against the hydroxyl radicals. Despite this, purification of the protein is still needed for further examination to guarantee the safety of DRP use. Besides, another viable strategy is to use the probiotic $E$. coli Nissle 1917 for the over-expression of DRP, which produces neither hemolysin nor other toxins.

\section{Conclusion}

We hereby demonstrated the process flow of the discovery of a novel protein from natural products and subsequent identification as a disease resistance protein (DRP). The overexpression of DRP was facilitated in the recombinant $E$. coli using pRARE plasmid for codon optimization. The crude extract containing DRP displayed potent inhibitory effects against common bacterial pathogens and showed prebiotic activity on the growth of $L$. rhamnosus ZY cells. DRP also showed strong anti-oxidant activity against hydroxyl radicals. The results reveal that DRP is a powerful candidate for nullifying free radicals.

\section{Supplementary information}

Supplementary information accompanies this paper at https://doi. org/10.1186/s40643-020-00343-5.

Additional file 1: Figure S1. The deducded DNA sequence of DRP. Figure S2. The gel electrophoresis analysis of the construction of pET21a-DRP by colony PCR. The N1 and the N2 was the negative control by adding the W3110 colony and pET21a plasmid into the PCR reaction. The P indicates the positive control with the addition of DNA synthesis of DRP as a template into the PCR reaction. The number 1 to 4 represents each colony. The targeted size is $832 \mathrm{bp}$. Table $\mathbf{S 1}$. Inhibition zone results of DRP protein in different pathogen strains.

\section{Acknowledgements}

The authors are grateful for the financial support received for this project from the Ministry of Science and Technology (MOST 108-2218-E-006-006 and MOST 109-2218-E-006-015) in Taiwan.

\section{Authors' contributions}

ISN and SIT designed the experiment and analyzed the data, SSWE and SIT performed all of experiments. ISN, SSWE and SIT wrote the manuscript. CHC, JSC and CYC gave conceptual suggestion. All authors read and approved the final manuscript.

\section{Funding}

The authors are grateful for the financial support received from the Ministry of Science and Technology (MOST 108-2218-E-006-006 and MOST 109-2218-E006-015) in Taiwan.

\section{Availability of data and materials}

The authors approved the availability of data and materials for publishing the manuscript.

\section{Ethics approval and consent to participate}

All the authors have read and agreed the ethics for publishing the manuscript.

\section{Consent for publication}

The authors approved the consent for publishing the manuscript.

\section{Competing interests}

The authors declare that they have no competing interests.

\section{Author details}

${ }^{1}$ Department of Chemical Engineering, National Cheng Kung University, Tainan 701, Taiwan. ${ }^{2}$ University Center for Bioscience and Biotechnology, National Cheng Kung University, Tainan, Taiwan. ${ }^{3}$ Department of Chemical and Materials Engineering, College of Engineering, Tunghai University, Taichung, Taiwan. ${ }^{4}$ Research Center for Energy Technology and Strategy, National Cheng Kung University, Tainan, Taiwan.

Received: 25 May 2020 Accepted: 14 October 2020

Published online: 26 October 2020

\section{References}

Allen J, Unlu S, Demirel Y, Black P, RiekhofW (2018) Integration of biology, ecology and engineering for sustainable algal-based biofuel and bioproduct biorefinery. Bioresour Bioprocess 5(1):47

Coon JJ, Syka JE, Shabanowitz J, Hunt DF (2005) Tandem mass spectrometry for peptide and protein sequence analysis. Biotechniques 38(4):519-523

Demay J, Bernard C, Reinhardt A, Marie B (2019) Natural products from Cyanobacteria: focus on beneficial activities. Mar Drugs 17(6):320

Easwar RD, Viswanatha CK (2020) Changes in the antioxidant intensities of seven different soybean (Glycine max (L.) Merr.) cultivars during drought. J Food Biochem 44(2):e13118

Eriksen NT (2008) Production of phycocyanin - a pigment with applications in biology, biotechnology, foods and medicine. Appl Microbiol Biotechnol $80(1): 1-4$

Gammoudi S, Athmouni K, Nasri A, Diwani N, Grati I, Belhaj D, Bouaziz-Ketata H, Fki L, El Feki A, Ayadi H (2019) Optimization, isolation, characterization and hepatoprotective effect of a novel pigment-protein complex (phycocyanin) producing microalga: Phormidium versicolor NCC-466 using response surface methodology. Int J Biol Macromol 137:647-656

Gillor O, Etzion A, Riley MA (2008) The dual role of bacteriocins as anti-and probiotics. Appl Microbiol Biotechnol 81(4):591-606

Guan X, Qin S, Su Z, Zhao F, Ge B, Li F, Tang X (2007) Combinational biosynthesis of a fluorescent cyanobacterial holo-a-phycocyanin in Escherichia coli by using one expression vector. Appl Biochem Biotechnol 142(1):52-59

Gupta S, Bhatt P, Chaturvedi P (2018) Determination and quantification of asiaticoside in endophytic fungus from Centella asiatica (L.) Urban. World J Microbiol Biotechnol 34(8):111

Huang G, Lin Y, Zhang L, Yan Z, Wang Y, Liu Y (2019) Synthesis of sulfur-selenium doped carbon quantum dots for biological imaging and scavenging reactive oxygen species. Sci Rep 9(1):1-9

Imbimbo P, Romanucci V, Pollio A, Fontanarosa C, Amoresano A, Zarrelli A, Olivieri G, Monti DM (2019) A cascade extraction of active phycocyanin and fatty acids from Galdieria phlegrea. Appl Microbiol Biotechnol 103(23-24):9455-9464

Jiang L, Wang Y, Yin Q, Liu G, Liu H, Huang Y, Li B (2017) Phycocyanin: a potential drug for cancer treatment. J Cancer 8(17):3416

Kaur P, Purewal SS, Sandhu KS, Kaur M (2019) DNA damage protection: an excellent application of bioactive compounds. Bioresour Bioprocess $6(1): 2$

Lai YC, Chang CH, Chen CY, Chang JS, Ng IS (2019) Towards protein production and application by using Chlorella species as circular economy. Bioresour Technol 289:121625

Li SY, Ng IS, Chen PT, Chiang CJ, Chao YP (2018) Biorefining of protein waste for production of sustainable fuels and chemicals. Biotechnol Biofuels $11(1): 1-5$

Liu Z, Zhen Z, Zuo Z, Wu Y, Liu A, Yi Q, Li W (2006) Probing the catalytic center of porcine aminoacylase 1 by site-directed mutagenesis, homology modeling and substrate docking. J Biochem 139:421-430

Mahmoudi R, Aghaei S, Salehpour Z, Mousavizadeh A, Khoramrooz SS, Taheripour SM, Christiansen G, Baneshi M, Karimi B, Bardania H (2020) Antibacterial and antioxidant properties of phyto-synthesized silver nanoparticles using Lavandula stoechas extract. Appl Organomet Chem 34(2):e5394 
Marchand JA, Neugebauer ME, Ing MC, Lin Cl, Pelton JG, Chang MC (2019) Discovery of a pathway for terminal-alkyne amino acid biosynthesis. Nature 567(7748):420-424

Marzorati S, Schievano A, Idà A, Verotta L (2020) Carotenoids, chlorophylls and phycocyanin from Spirulina: supercritical CO 2 and water extraction methods for added value products cascade. Green Chem 22(1):187-196

Najdenski HM, Gigova LG, Iliev II, Pilarski PS, Lukavský J, Tsvetkova IV, Ninova MS, Kussovski VK (2013) Antibacterial and antifungal activities of selected microalgae and cyanobacteria. Int J Food Sci Technol 48(7):1533-1540

Ng IS, Ye C, Li Y, Chen BY (2016) Insights into copper effect on Proteus hauseri through proteomic and metabolic analyses. J Biosci Bioeng 121(2):178-185

Patel HM, Rastogi RP, Trivedi U, Madamwar D (2018) Structural characterization and antioxidant potential of phycocyanin from the cyanobacterium Geitlerinema sp. H8DM. Algal Res 32:372-383

Quan Y, Yang S, Wan J, Su T, Zhang J, Wang Z (2015) Optimization for the extraction of polysaccharides from Nostoc commune and its antioxidant and antibacterial activities. J Taiwan Inst Chem Eng 52:14-21

Rani RP, Anandharaj M, Ravindran AD (2018) Characterization of a novel exopolysaccharide produced by Lactobacillus gasseri FR4 and demonstration of its in vitro biological properties. Int J Biol Macromol 109:772-783

Rosano GL, Ceccarelli EA (2014) Recombinant protein expression in Escherichia coli: advances and challenges. Front Microbiol 5:172

Sánchez-Moreno C (2002) Methods used to evaluate the free radical scavenging activity in foods and biological systems. Food Sci Technol Int 8(3):121-137

Santiago-Morales IS, Trujillo-Valle L, Márquez-Rocha FJ, Hernández JF (2018) Tocopherols, phycocyanin and superoxide dismutase from microalgae: as potential food antioxidants. Appl Food Biotechnol 5(1):19-27

Schlegel S, Genevaux P, de Gier JW (2017) Isolating Escherichia coli strains for recombinant protein production. Cell Mol Life Sci 74(5):891-908

Sezonov G, Joseleau-Petit D, d'Ari R (2007) Escherichia coli physiology in LuriaBertani broth. J Bacteriol 189(23):8746-8749

Sies H (1993) Strategies of antioxidant defense. Eur J Biochem 215(2):213-219

Silhavy TJ, Kahne D, Walker S (2010) The bacterial cell envelope. Cold Spring Harb Perspec Biol 2(5):a000414

Singh RK, Tiwari SP, Rai AK, Mohapatra TM (2011) Cyanobacteria: an emerging source for drug discovery. J Antibiot 64(6):401-412

Tan SI, Ng IS, Yu YJ (2017) Heterologous expression of an acidophilic multicopper oxidase in Escherichia coli and its applications in biorecovery of gold Bioresour Bioprocess 4(1):1-10
Tegel H, Tourle S, Ottosson J, Persson A (2010) Increased levels of recombinant human proteins with the Escherichia coli strain Rosetta (DE3). Protein Expr Purif 69(2):159-167

Teuling E, Schrama JW, Gruppen H, Wierenga PA (2019) Characterizing emulsion properties of microalgal and cyanobacterial protein isolates. Algal Res 39:101471

Waghmare AG, Salve MK, LeBlanc JG, Arya SS (2016) Concentration and characterization of microalgae proteins from Chlorella pyrenoidosa. Bioresour Bioprocess 3(1):16

Wang Y, Feng C, Yan L (2017) Enhancement of emerging contaminants removal using fenton reaction driven by $\mathrm{H}_{2} \mathrm{O}_{2}{ }^{-}$producing microbial fuel cell. Chem Eng J 307:679-686

Wolters DA, Washburn MP, Yates JR (2001) An automated multidimensional protein identification technology for shotgun proteomics. Anal Chem 73(23):5683-5690

Xia F, Fan J, Zhu M, Tong H (2011) Antioxidant effects of a water-soluble proteoglycan isolated from the fruiting bodies of Pleurotus ostreatus. J Taiwan Inst Chem Eng 42(3):402-407

Yu P, Li P, Chen X, Chao X (2016) Combinatorial biosynthesis of Synechocystis PCC6803 phycocyanin holo-a-subunit (CpcA) in Escherichia coli and its activities. Appl Microbiol Biotechnol 100(12):5375-5388

Zayadi RA, Bakar FA (2020) Comparative study on stability, antioxidant and catalytic activities of bio-stabilized colloidal gold nanoparticles using microalgae and cyanobacteria. J Environ Chem Eng 10:103843

Zhang L, Liu C, Li D, Zhao Y, Zhang X, Zeng X, Yang Z, Li S (2013) Antioxidant activity of an exopolysaccharide isolated from Lactobacillus plantarum C88. Int J Biol Macromol 54:270-275

Zhang J, Liu L, Ren Y, Chen F (2019) Characterization of exopolysaccharides produced by microalgae with antitumor activity on human colon cancer cells. Int J Biol Macromol 128:761-767

Zhao KH, Su P, Li J, Tu JM, Zhou M, Bubenzer C, Scheer H (2006) Chromophore attachment to phycobiliprotein $\beta$-subunits phycocyanobilin: Cysteine- $\beta 84$ phycobiliprotein lyase activity of $C$ peS-like protein from Anabaena sp. PCC7120. J Biol Chem 281(13):8573-8581

\section{Publisher's Note}

Springer Nature remains neutral with regard to jurisdictional claims in published maps and institutional affiliations.

\section{Submit your manuscript to a SpringerOpen ${ }^{\odot}$ journal and benefit from:}

- Convenient online submission

- Rigorous peer review

- Open access: articles freely available online

- High visibility within the field

- Retaining the copyright to your article

Submit your next manuscript at $\boldsymbol{\nabla}$ springeropen.com 